\title{
Discipline The Body Through The Fitness Centre During and After The Covid-19 Pandemic
}

\author{
Teguh Dwi Putranto ${ }^{1}$, Bagong Suyanto ${ }^{2}$, Septi Ariadi ${ }^{3}$ \\ ${ }^{1,2,3}$ Faculty of Social and Political Science, Airlangga University, Surabaya, Indonesia \\ e-mail: teguh.dwi.putranto-2019@fisip.unair.ac.id ${ }^{1}$
}

\begin{abstract}
Article Info
Article history:

Received

August $6^{\text {th }}, 2021$

Revised

December $3^{\text {rd }}, 2021$

Accepted

December $4^{\text {th }}, 2021$

Published

January $1^{\text {th }}, 2022$

\section{Abstract}

One of the sectors affected by the Covid-19 pandemic is the economic sector. Fitness centres are one of the industries affected by this pandemic due to government policies in imposing social restrictions on social distancing to reduce the spread of the corona virus. The purpose of this study was to clarify how a fitness center's communication strategy as part of a capitalist industry, such as an urban athlete, would train during and after the Covid 19 pandemic. The method used in this study is Krippendorff content analysis on Instagram @ urban.athletes posts from January 2021 to February 2021. The results of the research are coding have been carried out on five indicators, Advertising and Public Relations and Publicity indicators dominateInstagram @urban.athletes posts regarding marketing communication strategies. In conclusion, Urban Athletes uses fantasy to revive the sporting lifestyle during and after the Covid 19 pandemic. The body mediates the state during the pandemic. Urban athletes use the bodies in a disciplined manner to follow a lifestyle of sports to keep their bodies fit during a pandemic.
\end{abstract}

Keywords: discipline; fitness centre; urban athletes; covid-19 pandemic

Kata Kunci: disiplin; pusat kebugaran; urban athletes; pandemi covid19 


\section{INTRODUCTION}

COVID19 is the latest infectious coronavirus disease discovered. Prior to the discovery and outbreak of a pandemic in Wuhan, China in December 2019, the virus and disease were unknown (Hopkinsmedicine. org, 2020). COVID-19 has been declared a pandemic by the World Health Organization (WHO) as the number of confirmed cases approaches 200 000, with over 8000 deaths in more than 160 countries (WHO, 2020b). COVID-19 has an impact on several countries, including Indonesia. Indonesia reported the first case of coronavirus on March 2, 2020 (Nugroho, 2020). Indonesia has declared the coronavirus disease pandemic (COVID-19) a "serious calamity." After the government ordered individuals to "Stay at Home" and "Work from Home" in order to stop the spread of the coronavirus, the public got perplexed (Soekiman et al., 2021).

The Coronavirus Disease 2019 (Covid-19) pandemic has rendered several industries inoperable. Aside from health, the economic sector wields significant power in a number of countries, most notably in Indonesia (Budhiman, 2020). With the worldwide social constraints policy, the COVID19 has created a new way of life (Pujarama, 2021). Due to large-scale restrictions, there are severe economic losses, industry, and business disruptions at all levels of life during the COVID-19 pandemic (Caraka et al., 2020). The ris ing prevalence of COVID-19 had a significant impact on the global economy, potentially jeopardizing Indonesia's stability. The economic impact of the COVID-19 pandemic in Indonesia. The COVID-19 pandemic has had an impact on transportation, tourism, trade, health, and other sectors (Susilawati et al., 2020). So far, the government's policy responses have been aimed at righting the ship, addressing the needs of the poor as well as potentially poor (vulnerable) groups. At the time of writing, Covid-19 had not been tamed in any way in Indonesia. As a result, its implications for economic growth, jobs, and welfare remained unknown, as policy discussions cantered on freeing the economy from virus-imposed restrictions across the country, dubbed the "new normal" (Olivia et al., 2020). One of the industries in the economic sector that is affected by social restrictions due to the Covid-19 pandemic is a fitness centre, one of which is Urban Athletes.

Urban Athletes is a place for those who want to be inspired to live a healthy life. Urban Athletes believe that health that is visible on the outside comes from health that has been cultivated from within. Along with the development of the times and the activities that continue to increase, Urban Athletes sees more and more people who do not care about health. This motivates Urban Athletes to provide a special place for those who want to make healthy living as a lifestyle with the right and fun method (Urbanathletes, 2017).

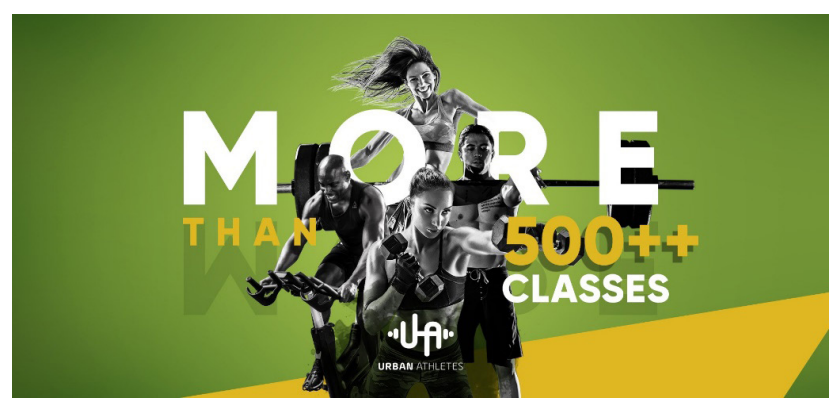

Figure 1. Urban athletes view

(Source: Urbanathletes, 2017)

Urban Athletes as an indoor fitness centre is also affected, because indoor sports (indoor) have a higher risk of contracting this virus infection due to factors such as closed room conditions, the number of people in the sports room, and the ease with which it spreads. As a result, strict and precise protocols are required, including avoiding physical contact or being too close to other people or objects that can be contaminated (Dominski \& Brandt, 2020). Urban Athletes is a fitness centre located in Surabaya which currently has 4 branches, namely Gunawangsa Apartment (Merr), Marvell City, Gunawangsa Apartment (Tidar), and Urban Athletes Lenmarc Mall.

Not only Indonesia, but many European countries also established restrictions and legislation in response to the widespread spread of a newCoronavirus (SARS-CoV-2), to decrease social connections and restrict the virus's transmission. Beginning March 22, 2020, German authorities imposed a shutdown on all non-essential infrastructure. Sports clubs, fitness centres, and community sports grounds were all closed because of these rules. Most federal states made it illegal to have social gatherings of more than two persons, limiting possibilities to enjoy sports and exercise with others (Mutz \& Gerke, 2020)many European governments enacted rules and legislations in order to reduce social interactions and contain the spread of the virus. German authorities put in force a lockdown of all non-essential infrastructure, starting on 22 March 2020. These policies included the closing of sports clubs, fitness centres and community sports grounds. Most federal states prohibited social gatherings of more than two people, thereby further restricting opportunities to play sport and exercise 
together. The paper addresses how Germans adapted their leisure time sport and exercise (LTSE. Many additional stores, restaurants, pubs, music theatres, and indoor sports centres have been ordered to close by authorities. Many government authorities are presently (May-June 2020) allowing a phased re-opening as part of COVID-19 (semi)lock-down exit measures, with indoor sport centres sometimes being the last in line to be allowed to re-open. This technical brief examines the problems of safely reopening these facilities, as well as the solutions proposed by others to address some of these issues (Blocken et al., 2020)the SARS-CoV-2 virus has managed to spread across the world. This virus can spread by close contact, which includes large droplet spray and inhalation of microscopic droplets, and by indirect contact via contaminated objects. While in most countries, supermarkets have remained open, due to the COVID-19 pandemic, authorities have ordered many other shops, restaurants, bars, music theaters and indoor sports centers to be closed. As part of COVID-19 (semi. Even though the metabolic equivalent of a task is used to calculate the intensity of physical exertion. 1 While duties of everyday living can help a person fulfil the prescribed amount of physical activity per week (Piercy et al., 2018)function, and sleep better and reduce risk of many chronic diseases. OBJECTIVE To summarize key guidelines in the Physical Activity Guidelines for Americans, 2nd edition (PAG.

If they are able, all individuals, even those with chronic medical issues, should engage in at least 150 minutes to 300 minutes of moderate-intensity exercise per week, according to the US Physical Activity Guidelines (Piercy et al., 2018)function, and sleep better and reduce risk of many chronic diseases. OBJECTIVE To summarize key guidelines in the Physical Activity Guidelines for Americans, 2nd edition (PAG. Even though, World Health Organization (WHO) also recommends 150-300 minutes of moderate-intensity exercise per week, or 75-150 minutes of strenuous exercise, or a combination of the two. Although sports like this can be done at home without the use of equipment, even in a confined space, they are not appropriate for a gym or a fitness centre (Quarantrain.org, 2020). Because there is an increase in mental stress and uncertainty surrounding many matters, including family, financial, and medical practice, including conducting physical and exercise activities utilizing the above recommendations, wellness for allergy and immunology physicians is crucial during the COVID-19 pandemic (Nyenhuis et al., 2020), and Physical activity is one of the things that needs to be done on a daily basis. Exercising daily can have a therapeutic effect and restore normalcy to life (Furkan et al., 2021). Physical activity has been shown to help with the clinical symptoms that are most linked with severe COVID-19. Physical activity lowers both systolic and diastolic blood pressure and helps to remodel left ventricular hypertrophy, lowering overall cardiovascular risks. Physical activity stimulates the immune system, and the extent of the reaction is proportional to the time and intensity of the exercise. Moderate-intensity exercise training has been linked to a lower risk (Airlangga, 2021).

But WHO does not recommend the use of masks when exercising because masks can reduce the ability to breathe comfortably, and the sweat produced when exercising causes masks to become wet and moist so that it is more difficult to breathe and encourages the growth of opportunistic micro-organisms. The most important precaution to take when exercising is to maintain the recommended physical distance. Exercise is very beneficial for physical and mental health, but its implementation during this pandemic must be done in a safe and appropriate manner to limit the massive spread of COVID-19 (WHO, 2020a). Of course, this is a challenge for fitness centres, one of which is Urban Athletes in running a business in the field. Even though one way to maintain and improve health, especially during the Covid-19 pandemic, is by exercising, because health is something that is important in human life because health is needed to carry out daily activities.

This has certainly led to a decrease in the number of members who will carry out sports activities at Urban Athletes and prospective members who will participate in Urban Athletes for safety reasons during the Covid-19 pandemic, as well as for reasons of social restrictions and the use of masks when exercising. With this in mind, this study shows how fitness center communication strategies as part of a capitalist industry like Urban Athletes train during and after the Covid 19 pandemic on Instagram. The purpose is to clarify. The theory used in this study is Foucault's theory of power, which holds that power is inextricably linked to knowledge: there is no power without knowledge, and there is no knowledge without power. However, knowledge and power are not synonymous. On the one hand, knowledge has a powerful influence, while power necessitates knowledge (Foucault, 1993) IN WHICH Michel Foucault talks to Paul Rabinow, makes its most general point last. Foucault argues that material changes cannot be used to explain changes in 
subjectivity. For instance, when, in the Middle Ages, chimneys were first walled and placed inside, rather than outside, houses, interpersonal relations were transformed. New interactions flourished around chimneys. But the building of chimneys is not enough to explain these changes - if, for instance, different discourses and values had been circulating at the time then chimneys would have produced different kinds of changes. Generalizing from this point, Foucault argues that abstract (and in the West highly valued.

\section{METHOD}

In this study, the content analysis method is used to describe the aspects and characteristics of the post content. content of a message and its transmission, and is an analytical tool for observing and analyzing the communication activity of selected communicators (Krippendorff, 2018). Content analysis is a systematic approach to assessing the content and transmission of messages and is an analysis tool for monitoring and analyzing accessible material in the communication activities of selected communicators (Kim, 2019);(Fiani et al., 2021). Researchers used two encoders to ensure the objectivity of coding and data collection. The reliability test used two encoders to determine the accuracy of the data and to verify the validity of the collected data. The reliability test used two encoders to verify the validity of the collected data and determine the accuracy of the data. Next, the researchers looked at Krippendorff's Instagram content. From January 2021 to February 2021, researchers used content analysis to explore Urban Athlete's digital marketing communication strategies on Instagram @ urban.athletes.

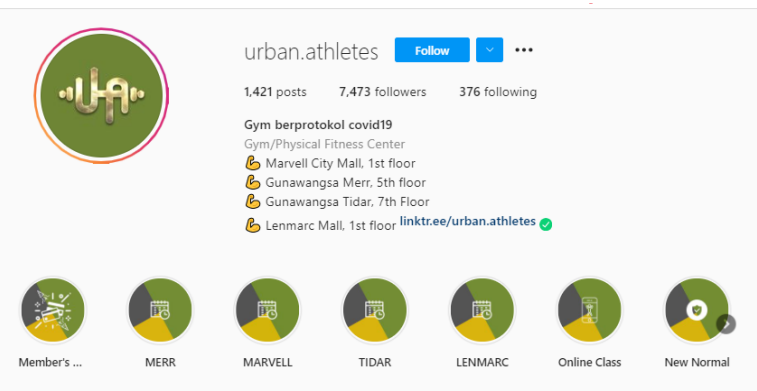

Figure 2. Urban athletes instagram profile

(Source: Urbanathletes, 2021)

The Holsti formula is used in this study to compute data from two coders (Samiei \& Mehrabi, 2019). The content analysis method was chosen because researchers tried to quantitatively review the content of Instagram posts before attempting to interpret the posted content of Instagram @ urban. athletes posts, read symbols, or interpret symbolic interaction content.

The researcher uses the following steps in this content analysis method: first, the researcher looks at Instagram @urban.athletes posts from January 2021 to February 2021. Second, the researcher selects Instagram @urban.athletes to view posts that highlight Urban Athletes's digital marketing communications strategy on Instagram. Third, once the posts have been collected, the encoder will sort them. The collected data is then processed and analysed in the fourth step.

$$
\mathrm{PAo}=2 \mathrm{~A} /(\mathrm{N} 1+\mathrm{N} 2)
$$

Where PAo represents the percentage of agreement between two coders, A represents the number of decisions made by both coders, and N1 and $\mathrm{N} 2$ represent the number of decisions made by coders. This study's digital marketing communication strategy focuses on promotion include Advertising, Sales promotion, Public relations and publicity, Personal selling, and Direct marketing are all indicators in promotion (Kotler \& Armstrong, 2010).

Advertising is any non-personal presentation and promotion of a sponsor's idea, item, or service that requires money. Sales promotion is an attempt to buy or sell a product or service. Public relations and publicity are used to build rapport with various public companies for profit, to promote a positive corporate image, and to deal with or correct unfortunate rumours, stories, and events. Personal selling is a personalized presentation created by a company's sales force to generate sales transactions and build customer relationships. Direct marketing is the development of direct relationships with individual customers to elicit immediate responses while also establishing longterm customer relationships.

\section{RESULTS AND DISCUSSION}

Researchers collected 48 UrbanAthletes Instagram posts from @ urban.athletes and used Holsti's formula to assess the reliability of the data. Advertising indicators include advertising, promotion, public relations and public relations, personal sales, and direct marketing.

Table 1 shows the results of the encoder 1 and encoder 2 coding process at 48 posts. These are separated by date or indicator. In addition, Table 2 below outlines these indicators. 
Table 1. Analysis of Posts by Two Coders for January 2021 to February 2021

\begin{tabular}{ccccccccccc}
\hline \multirow{2}{*}{ Date } & \multicolumn{9}{c}{ Coder 1 } & \multicolumn{6}{c}{ Coder 2} \\
\cline { 2 - 10 } January & A & SP & PR & PS & DM & A & SP & PR & PS & DM \\
1 & - & - & 1 & - & - & 1 & - & - & - & - \\
2 & - & - & 1 & - & - & 1 & - & - & - & - \\
3 & - & - & - & - & - & - & - & - & - & - \\
4 & 1 & - & - & - & - & 1 & - & - & - & - \\
5 & 1 & - & - & - & - & 1 & - & - & - & - \\
6 & 1 & - & - & - & - & 1 & - & - & - & - \\
7 & - & - & 1 & - & - & - & - & 1 & - & - \\
8 & - & 1 & - & - & - & 1 & - & - & - & - \\
9 & - & - & 1 & - & - & 1 & - & - & - & - \\
10 & - & - & - & - & - & - & - & - & - & - \\
11 & - & - & 1 & - & - & - & 1 & - & - & - \\
12 & 1 & - & - & - & - & - & - & 1 & - & - \\
13 & 1 & - & - & - & - & - & - & 1 & - & - \\
14 & 1 & - & - & - & - & - & 1 & - & - & - \\
15 & 1 & - & - & - & - & - & - & 1 & - & - \\
16 & - & - & 1 & - & - & 1 & - & - & - & - \\
17 & - & - & - & - & - & - & - & - & - & - \\
18 & 1 & - & - & - & - & 1 & - & - & - & - \\
19 & - & 1 & - & - & - & - & 1 & - & - & - \\
20 & - & - & - & 1 & - & - & - & 1 & - & - \\
21 & 1 & - & - & - & - & - & - & 1 & - & - \\
22 & 1 & - & - & - & - & - & - & 1 & - & - \\
23 & - & - & 1 & - & - & 1 & - & - & - & - \\
24 & - & - & - & - & - & - & - & - & - & - \\
25 & 1 & - & - & - & - & - & - & 1 & - & - \\
26 & 1 & - & - & - & - & - & - & 1 & - & - \\
27 & - & - & - & 1 & - & - & - & 1 & - & - \\
28 & - & 1 & - & - & - & 1 & - & - & - & - \\
29 & - & - & - & 1 & - & 1 & - & - & - & - \\
30 & - & - & 1 & - & - & 1 & - & - & - & - \\
31 & - & - & - & - & - & - & - & - & - & -
\end{tabular}

February

$\begin{array}{lllllllll}1 & 1 & - & - & - & - & - & - & 1 \\ 2 & - & 1 & - & - & - & 1 & - & - \\ 3 & - & - & 1 & - & - & 1 & - & - \\ 4 & 1 & - & - & - & - & - & - & 1 \\ 5 & - & - & 1 & - & - & - & 1 & - \\ 6 & - & - & 1 & - & - & 1 & - & - \\ 7 & - & - & - & - & - & - & - & - \\ 8 & 1 & - & - & - & - & - & - & 1 \\ 9 & - & 1 & - & - & - & 1 & - & - \\ 10 & - & 1 & - & - & - & - & - & 1 \\ 11 & 1 & - & - & - & - & - & - & 1 \\ 12 & - & - & 1 & - & - & - & - & 1 \\ 13 & - & - & - & - & 1 & 1 & - & - \\ 14 & - & - & - & - & - & - & - & - \\ 15 & 1 & - & - & - & - & - & - & 1 \\ 16 & 1 & - & - & - & - & - & - & 1\end{array}$


IKOMIK: Jurnal Ilmu Komunikasi dan Informasi 1(2) 2021 65-72

\begin{tabular}{ccccccccccc}
\hline \multirow{2}{*}{ Date } & \multicolumn{3}{c}{ Coder 1 } & \multicolumn{5}{c}{ Coder 2 } \\
\cline { 2 - 10 } & A & SP & PR & PS & DM & A & SP & PR & PS & DM \\
\hline 17 & - & - & - & - & - & - & - & - & - & - \\
18 & 1 & - & - & - & - & - & - & 1 & - & - \\
19 & - & - & - & - & - & - & - & - & - & - \\
20 & - & - & - & - & 1 & - & 1 & - & - & - \\
21 & - & - & - & - & - & - & - & - & - & - \\
22 & 1 & - & - & - & - & - & - & 1 & - & - \\
23 & - & 1 & - & - & - & - & 1 & - & - & - \\
24 & 1 & - & - & - & - & - & - & 1 & - & - \\
25 & 1 & - & - & - & - & - & - & 1 & - & - \\
26 & - & 1 & - & - & - & - & - & 1 & - & - \\
27 & - & 1 & - & - & - & 1 & - & - & - & - \\
28 & - & - & - & - & - & - & - & - & - & - \\
\hline Total & $\mathbf{2 2}$ & $\mathbf{9}$ & $\mathbf{1 2}$ & $\mathbf{3}$ & $\mathbf{2}$ & $\mathbf{1 9}$ & $\mathbf{6}$ & $\mathbf{2 3}$ & $\mathbf{0}$ & $\mathbf{0}$ \\
\hline \multirow{*}{*}{ A: Advertising, SP: Sales Promotion, PR: Public Relations and Publicity, PS: } \\
\multicolumn{3}{c}{ Personal Selling, and DM: Direct Marketing } &
\end{tabular}

Table 2. Coder Output on Posts Instagram @urban.athletes

\begin{tabular}{lccc}
\hline \multirow{2}{*}{ Variable } & \multicolumn{3}{c}{ Coding Output } \\
\cline { 2 - 4 } & Coder 1 & Coder 2 & Agreement between two coders \\
\hline Advertising & 22 & 19 & 19 \\
Sales promotion & 9 & 6 & 6 \\
Public relations and publicity & 12 & 23 & 12 \\
Personal selling & 3 & 0 & 0 \\
Direct marketing & 2 & 0 & 0 \\
\hline \multicolumn{1}{c}{ Total } & 48 & 48 & 37 \\
\hline
\end{tabular}

$$
\begin{aligned}
\text { Pao } & =2 \mathrm{~A} /(\mathrm{N} 1+\mathrm{N} 2) \\
& =2(37) / 48+48 \\
& =74 / 96 \\
& =0,77(77 \%)
\end{aligned}
$$

The data is said to be reliable if it has a tolerance value of at least $70 \%$ or greater than $0.7 \%$ (Holsti, 1969). Based on the results of data calculations using the Coder Holsti reliability formula, the element of reliability is 0.77 , or 77 percent. As a result, the obtained data is declared reliable because it exceeds the minimum limit.

The results of coding have been carried out on five indicators, namely Advertising, Sales Promotion, Public Relations and Publicity, Personal Selling, and Direct Marketing. Advertising and Public Relations and Publicity indicators dominate Instagram @urban. athletes posts regarding marketing communication strategies.

Posts related to advertising on Instagram @ urban.athletes are indicated by posts containing resolutions in matters of a healthy lifestyle. However, if all this time the resolution of a healthy life has always ended up being a goal that has never been achieved, then there must be several things that must be changed. It is not only a matter of intentions that need to be stronger, but also a list of achievements that must be made more realistic. To achieve a healthy lifestyle, Urban Athletes through an Instagram post using \# AyoK KembaliKeUrbanAthletes (Let's go back to Urban Athletes) invites everyone to join and train with Urban Athletes.

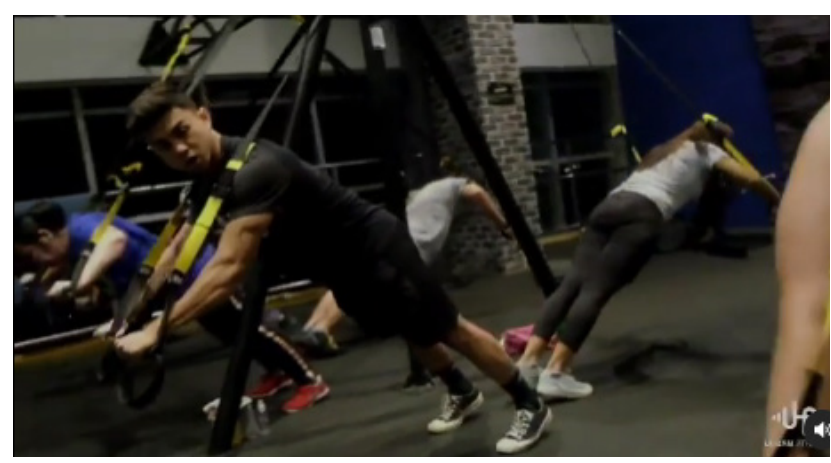

Figure 3. TRX suspension training (Source: Urbanathletes, 2021)

Recently, a healthy lifestyle has become a trend that is widely practiced. When talking about a healthy 
lifestyle, the first thing that comes to mind is sports. Right now, there are a lot of sports that are packaged in a more fun way, one of which is the TRX Suspension Training, namely the Total Body Resistance Exercise. As the name implies, TRX Suspension Training can help programs in losing weight and building muscle relatively quickly, helping them train after an injury to train their core muscles and improve posture.

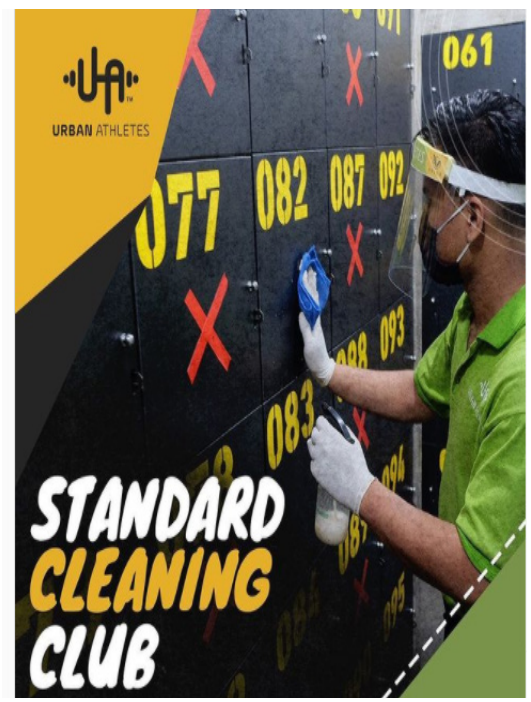

Figure 4. Cleaning sterilization standards (Source: Urbanathletes, 2021)

To maintain safety and comfort, Urban Athletes not only cleans the tool and class area, but the club cleaning sterilization standards also include bathrooms, lockers, and all other rooms where contact / touch with hands is possible, using disinfectants so that all feel safe when returning to exercise in Urban Athletes club.

Meanwhile, posts related to Public Relations and Publicity on Instagram @urban.athletes throughout the year 2020, health has been a hot topic of discussion. The reason for this is that the world's population has been subjected to an extraordinary event this year, namely the Covid-19 pandemic. The Corona virus forces us to alter our way of life, beginning with how we work, work rhythm, habits, focus, and attention. As a result, maintaining the body's immunity has become a hot topic in the last year. Of course, our focus in the new year 2021 will be on how to maintain a healthy body so that it is not susceptible to disease, particularly the Covid-19 virus.

From Foucault's perspective, one's bodybecomes the object of exploitation by capitalist industry. This makes the capitalist industry increasingly exploit this condition in mastering the imagination and fantasies of someone who is crazy about fitness.
These imaginations and fantasies eventually generate encouragement from fitness enthusiasts in disciplining the body through physical activity at the fitness centre. Urban Athletes as a capitalist industry engaged in services provides knowledge to the public, especially sports or fitness enthusiasts about the importance of maintaining body condition, especially during the Covid-19 pandemic through sports. But with the Covid-19 pandemic, of course, limited movement, so that outdoor sports are riskier to health, especially in places that are crowded with visitors.

This knowledge is what Urban Athletes want to impart so that people can exercise in indoor fitness centres such as Urban Athletes. Thus, a person gets satisfaction in getting a fit body condition during the Covid-19 pandemic by getting comfort in a safe place, and this comfort is provided by Urban Athletes through cleaning tools and class areas, which also includes sterilization cleaning which also includes bathrooms, lockers, and all other rooms that allow contact / hand contact, using disinfectants so that everyone feels safe when they return to exercising at the Urban Athletes club.

\section{CONCLUSION}

Advertising and Public Relations and Publicity are more engaged in a digital marketing communication strategy via Instagram @urban. athletes. Following the data analysis, the results show that the communication strategy carried out by Urban Athletes as a fitness centre as well as part of the capitalist industry in reviving the lifestyle of sports during and after the Covid-19 pandemic by providing fantasies to maintain body condition during a pandemic. So doing physical activity at Urban Athletes is one of the efforts that can be chosen. Urban Athletes uses the body to be disciplined to follow a lifestyle of sports so that the capitalist industry run by Urban Athletes can continue to run during a pandemic which makes the body vulnerable to weakness if it is not in a fit condition, so joining and training at Urban Athletes is the right choice in maintain body condition during a pandemic.

\section{REFERENCES}

Airlangga, M. (2021). Berolahraga Aman Di Masa Pandemi COVID-19. PROCEEDING UMSURABAYA.

Blocken, B., van Druenen, T., van Hooff, T., Verstappen, P., Marchal, T., \& Marr, L. (2020). Can indoor sports centers be allowed to re-open during the COVID-19 pandemic based on a certificate of equivalence? Building and Environment, 180. https://doi. org/10.1016/j.buildenv.2020.107022 
Budhiman, I. (2020). Terdampak Corona, Agen Properti Ubah Strategi Penjualan. https://ekonomi.bisnis. $\mathrm{com} / \mathrm{read} / 20200319 / 47 / 1215465 /$ terdampakcorona-agen-properti-ubah-strategi-penjualan

Caraka, R., Lee, Y., Kurniawan, R., Herliansyah, R., Kaban, P., Nasution, B., Gio, P., Chen, R., Toharudin, T., \& Pardamean, B. (2020). Impact of COVID-19 large scale restriction on environment and economy in Indonesia. Global Journal of Environmental Science and Management, 6, 65-84. https://doi. org/10.22034/GJESM.2019.06.SI.07

Dominski, F., \& Brandt, R. (2020). Do the benefits of exercise in indoor and outdoor environments during the COVID-19 pandemic outweigh the risks of infection? Sport Sciences for Health, 16(3), 583-588.

Fiani, I., Windrati, N., Arisanty, M., \& Dewi, D. (2021). Tipologi Gaya Video Instruksional di Universitas Terbuka TV. IKOMIK: Jurnal Ilmu Komunikasi Dan Informasi, 1(1), 40-47.

Foucault, M. (1993). Space, power, and knowledge. The Cultural Studies Reader.

Furkan, Rusdin, \& Shandi, S. (2021). Menjaga Daya Tahan Tubuh Dengan Olahraga Saat Pandemi Corona Covid-19. JISIP (Jurnal Ilmu Sosial Dan Pendidikan), $5(1)$.

Holsti, O. (1969). Content analysis for the social sciences and humanities. Reading, MA: Addison-Wesley.

Hopkinsmedicine.org. (2020). What Is Coronavirus? https:// www.hopkinsmedicine.org/health/conditions-anddiseases/coronavirus

Kim, H. (2019). Globalization and regulatory change: The interplay of laws and technologies in E-commerce in Southeast Asia. Computer Law and Security Review, 35(5), 1-20. https://doi.org/10.1016/j. clsr.2019.03.009

Kotler, P., \& Armstrong, G. (2010). Principles of marketing. Pearson education.

Krippendorff, K. (2018). Content analysis: An introduction to its methodology. Sage Publications.

Mutz, M., \& Gerke, M. (2020). Sport and exercise in times of self-quarantine: How Germans changed their behaviour at the beginning of the Covid-19 pandemic. International Review for the Sociology of Sport, 56(3), 305-316. https://doi. org/10.1177/1012690220934335

Nugroho, R. (2020). Rekap Kasus Corona Indonesia Selama Maret dan Prediksi di Bulan April. https://www. kompas.com/tren/read/2020/03/31/213418865/ rekap-kasus-corona-indonesia-selama-maret-danprediksi-di-bulan-april

Nyenhuis, S., Greiwe, J., Zeiger, J., Nanda, A., \& Cooke, A. (2020). Exercise and Fitness in the Age of Social Distancing During the COVID-19 Pandemic. Journal of Allergy and Clinical Immunology: In
Practice, 8(7), 2152-2155. https://doi.org/10.1016/j. jaip.2020.04.039

Olivia, S., Gibson, J., \& Nasrudin, R. (2020). Indonesia in the Time of Covid-19. Bulletin of Indonesian Economic Studies, 56(2), 143-174. https://doi.org/1 0.1080/00074918.2020.1798581

Piercy, K., Troiano, R., Ballard, R., Carlson, S., Fulton, J., Galuska, D., George, S., \& Olson, R. (2018). The physical activity guidelines for Americans. JAMA - Journal of the American Medical Association, 320(19), 2020-2028. https://doi.org/10.1001/ jama.2018.14854

Pujarama, W. (2021). The Urge to Hustle: Narratives of Mediated Higher Degree Learning Interaction among University Students during Covid-19 Pandemic. IKOMIK: Jurnal Ilmu Komunikasi Dan Informasi, 1(1), 1-8.

Quarantrain.org. (2020). Stay physically active during self_ quarantine. https://quarantrain.org/2020/03/18/ who-stay-physically-active-during-self-quarantine/

Samiei, D., \& Mehrabi, Z. (2019). Content analysis of the first chapter of the twelfth grade chemistry book based on the william romey's method and determining its importance with the shannon entropy method. 1(3), 53-72. https://www.sid.ir/en/journal/ViewPaper. aspx?ID=720429

Soekiman, J., Putranto, T., Susilo, D., \& Garcia, E. (2021). Economic Sector during the COVID-19 Pandemic: Indonesian Instagram Users Behaviour. Webology, 18(1).

Susilawati, S., Falefi, R., \& Purwoko, A. (2020). Impact of COVID-19's Pandemic on the Economy of Indonesia. Budapest International Research and Critics Institute (BIRCI-Journal): Humanities and Social Sciences, 3(2). https://doi.org/10.33258/birci. v3i2.954

Urbanathletes. (2017). About us. http://urbanathletes.co.id/ Urbanathletes. (2021a). @urban.athletes Instagram post on January 5, 2021. https://www.instagram.com/p/ CJprU8ullfC/

Urbanathletes. (2021b). @urban.athletes Instagram post on January 6, 2021. https://www.instagram.com/p/ CJsNyESFJqv/

Urbanathletes. (2021c). Urban athletes instagram profile. https://www.instagram.com/urban.athletes/

WHO. (2020a). Coronavirus Disease (COVID-19). https:// www.heart.org/en/healthy-living/fitness/fitnessbasics/why-is-physical-activity-so-important-forhealth-and-wellbeing

WHO. (2020b). Coronavirus disease (COVID-19) outbreak. https://www.who.int/docs/default-source/ coronaviruse/situation-reports/20200601-covid-19sitrep-133.pdf?sfvrsn=9a56f2ac_4 